https://doi.org/10.18485/poet_srp_real.2018.ch6

\author{
Ана С. Живковић ${ }^{1}$ \\ Универзитет у Крагујевцу ${ }^{2}$ \\ Филолошко-уметнички факултет \\ Катедра за српску књижевност
}

\title{
СЛИКА - ПРОЗНИ ЖАНР СРПСКОГ РЕАЛИЗМА
}

Овим истраживањем испитујемо „слику” као жанровску и међужанровску категорију прозе српског реализма. Стратегија естетизације света делује конструисањем тачке гледишта гледаоца и обликује се захваљујући моделу метафоре позоришта, што може објаснити присуство термина „слика" у делима сва три књижевна рода. Циљ овога рада усмерен је на процес канонизације жанра, померање слике са периферије система у његов центар, као и на обрнуту појаву - деканонизацију слике - у којој кључну улогу има пародија. Примењујући идеолошку, структуралистичку и семиотичку методу, издвајамо кључне композиционе поступке у слици: „оквир”, путовање као мотивацију, описе природе, ентеријера и екстеријера, сусрет са новим јунацима, технику „сказа”, дијалог, одлазак из приказаног простора.

\footnotetext{
1 ja.zanita@yahoo.com

${ }^{2}$ Овај рад је део истраживања која се изводе на пројекту 178025 Поейика срйскоі реализма, који финансира Министарство просвете и науке Републике Србије.
} 
Кључне речи: „слика”, жанр, реализам, метафора позоришта, естетизација, историја чула

У досадашњој литератури о „слици” као естетичкој, жанровској и међужанровској одредници указивано је на сродност овог термина са још неколицином генолошки недефинисаних одредница 3 . Књижевна критика и теорија књижевности крајем 19. и почетком 20. века процењивале су жанрове у зависности од квантитета, јер су истоветни стваралачки принципи, анегдотски пре свега, замаглили присутне структуралне неподударности. У том смислу и приповетка је представљала „недовољно издиференцирану, дифузну форму која стоји између новеле и романа и понекад укључује обе те врсте" (Деретић 1981: 145). Под реалистичким романом подразумевало се прозно дело оп-

${ }^{3}$ У својој студији Срйска йритовијетика између романииике и реализма (1865-1875) Душан Иванић скренуо је пажњу на чињеницу да термин „слика” превазилази димензије жанра и „упозорава на масовно преобликовање како свијести о приповједним формама, тако и самих тих форми" (Иванић 1976: 101). У истом раду потцртана је активност писаца, преводилаца и уредника часописа, који су у периоду од 1865. до 1875. године уносили у наслове и поднаслове не само одредницу „слика” већ и следеће термине: путничка црта, слика из времена, црта из народног живота, хумореска, одсек из ђаковања, приповетка из летње ноћи, један романчић из живота (в. Иванић 1976: 101). Напоменули смо овде само неколико таквих примера ради илустрације појаве о којој је реч. У нашем раду само ћемо донекле обухватити заједничка обележја ових наслова и поднаслова, будући да је предмет нашег интересовања „слика” као жанровска и међужанровска одредница. Од споменутих термина само су се „слика”, „црта” и „цртица” издвојиле као најучесталије ознаке, поготово ако узмемо у обзир њихову широку примењивост, од књижевности до науке и публицистике, те еволуцију током епохе реализма настављену и у прози српске модерне. Из тих разлога, „слику" ћемо самеравати и упоређивати пре свега са овим двема формама. 
сежније грађе са знатно већим бројем страница но што је приповетка имала. Мерила према квантитету определила су и слику као жанр реалистичке прозе ${ }^{4}$. Слика као засебна приповедна форма епохе реализма разумевана је превасходно у смислу мале приповедне форме, скромнијег обима у односу на приповетку, док су се пропратне жанровске посебности уочавале од стране књижевних критичара тек након сагледавања овог првог плана 5 . Сабирајући све недостатке приповедака Милорада Поповића Шапчанина, аутора у чијем је опусу термин „слика” употребљен након што је Јаков Игњатовић први то учинио ${ }^{6}$, Милан Савић ће нам заправо скицирати основне претпоставке слике као жанра: „Те су приповетке добре фотографије, али на тај начин и без живота, без акције, без страсног кретања, без психолошког или бар стварног заплета" (Савић 1880: 126). Статичност и дефабулативност издвојиле су се као пресудни моменти приликом диференцирања слике и приповетке. Неколико година касније, чланком Милана Јовановића у Отиаибини поводом прве књиге Јанка Веселиновића Слике из сеоскої животиа (1886), осветљавање жанровског идентитета слике допуњено је новим етичким

4 Приметивши у критици Милана Савића (в. Савић 1881: 3031 ) и Данила Живаљевића (в. Живаљевић 1890: 439) успостављање одређених мерила за конципирање поетике слике, Душан Иванић је закључио да „у поређењу са приповијетком 'слика' има мање умјетничке захтјеве, композиција и радња су мање развијене" (Иванић 1990: 304).

5 Говорећи о књигама Милорада Поповића Шапчанина, Милан Савић разликује слику од приповетке, назива слику „фотографијом”, будући да препознаје некакав посебни „Шапчанинов жанр описивања" (Савић 1880: 129).

6 Дело Јакова Игњатовића „Једна женидба” објављивано је у наставцима први пут у Даниии (Дании, а, III, 1862, бр. 1-11) са поднасловом „Слика из живота од Јакова Игњатовића”. 
критеријумом: „да у друштву подржава оно што је добро и лепо" (Јовановић 1987: 246). Осим тога, у истом критичком раду сугерисана је различитост „фотографије” у односу на слику, што нам доказује да слика, премда настала с намером поистовећивања са стварношћу, ради „фотографисања" реалности, ипак, крајем епохе бива препозната као форма која не износи нагу реалност, будући да су „фотографије” појединих француских новелиста „грозно верне али без идеална колорита" (Јовановић 1987: 245). Корак даље у разграничавању слике и приповетке у српској теорији жанра представљају књижевне критике Љубомира Јовановића који, упоређујући ране књижевне радове Илије Вукићевића са потоњим, јасно објашњава стање прелазности - од старе ка новој врсти - наводећи аргументе у прилог претпоставци о могућностима постојања новог жанровског модела: обично један интиман душевни догађај, испричана судбина јунака у неколико реченица, осликавање душе јасним и брзим потезима, приповедна живахност, једна анегдота или епизода (в. Јовановић 1972: 170-173). Оно што је важно за наше истраживање нарочито се односи на Јовановићево опажање смене утицаја и извора у српској реалистичкој литератури, будући да препознаје дејство Тургењевљевих Ловчевих зайиса у низу Вукићевићевих дела. Слика се опредељује као форма у којој је концентрована читава садржина пространије приповетке, као скицирана грађа која може послужити приликом изградње великих композиција, али се пажња у сликама управља на једно лице, за разлику од ситуације у приповеци и роману, где се сусрећемо са знатно већим бројем ликова. Слике, према Љубомиру Јовановићу, функционишу углавном као портрети у ликовној уметности (в. Јовановић 1972: 172). Премда се сами жанр мењао упливом модернистичких елемената, задржавао је основну наративну структуру, што нам посведочава Јован Скерлић 
у предговору Сликама из животиа (1904) Светолика Ранковића казујући како „приповетке изгледају као материјал за писање романа, као они нацрти које сликари бележе у своје блокове, да их после унесу у велике композиције" (Скерлић 1904: XXVII). Истражујући савременије апостериорно књижевно-критичко промишљање овог жанра, налазимо класификацију Драгише Живковића који трећу групу наративних јединица Вукићевићевог опуса одређује као „циклус приповедака и слика са тематиком из граничарског живота" (Живковић 1982: 131), на основу чега закључујемо да се разликовање жанровског идентитета приповетке и слике усталило у дијахронијској перспективи. Историчар књижевности закључује да српска приповедна књижевност овим циклусом слика не открива само нови амбијент већ и нове видове једне егзотичне прозе. Спој егзотичне тематике са, у то време модерним, натуралистичким проседеом завређује научно интересовање и подробније испитивање. Драгана Чорбић поводом слике казује:

„Жанровском номенклатуром се потенцирала миметичност исприповеданог и тиме се појму жанра придавало једно ново значење - дело је постојало вероватно у односу на два система норми: у односу на правила жанра и у односу на дискурс и оно што читалац мисли да је стварно." (Чорбић Вукићевић 1998: 58)

Будући да се „слика” током епохе реализма појављивала у насловима и поднасловима не само епских већ и лирских и драмских литерарних остварења, најпрецизније би било говорити о „слици” као међужанровској ознаци ${ }^{7}$, међутим, с обзиром на то да постоји могућност издвајања једног хомогеног жанровског језгра формираног

7 „Слика” као међужанровска одредница предмет је рада Душана Иванића „Слика - међужанровска ознака у српској књижевности епохе реализма” (в. Иванић 1990: 301-307). У нашем раду првенствено ће бити разматрано жанровско значење „слике”. 
у границама реалистичке прозе, у овом раду усмерићемо пажњу пре свега на „слику” као прозни жанр српског реализма, имајући у виду сазнање да овај термин „има широк распон значења од краће приче до романескне пуноће, и од миметичког сликања разних призора из живота све до драмске тензије и лирских расположења" (Живковић 1994: 209). Покушаћемо стога да осветлимо неколике заједничке особености књижевних дела, чија је природа обележена термином „слика”, како бисмо потом разликовали жанровско од међужанровског значења. Проблем приликом тумачења овог термина сложенији је но што се чини, јер се „слика” и као жанровска и као међужанровска одредница појављује и у другим језицима и књижевностима ${ }^{8}$. Поред тога што улази у (под)наслове српских романескних дела крајем епохе (Лазар Комарчић, Мој кочијаш: слике из 1883. іоguне) $)^{9}$, примећујемо сличност и са одредницом 'la scène' која се налази у насловима Бал-

8 Драгиша Живковић даје упоредни преглед жанровског значења „слике” у српском, немачком, француском и руском језику: (1) у српској књижевности „слика” има ознаке краћег приповедног жанра; (2) у немачкој литератури „термин 'Genrebild' управо је идентичан са нашим називом 'слика'" (Живковић 1994: 210); (3) у француској књижевности реч „'le tableau' има и значење 'le recit', што би одговарало и нашем жанровском значењу те речи" (Живковић 1994: 208); (4) „слика” означава и опис, запис, белешку о неком аутентичном догађају, стога је „блиска оном жанровском појму који се означава руским називом 'очерк'" (Живковић 1994: 211). Поред издвојених примера, аутор је навео и низ општеестетичких и жеђужанровских значења ових страних термина, који усложњавају препознавање „слике” као самосталног жанра у европским књижевностима.

${ }^{9}$ На ту појаву скренуо нам је пажњу Душан Иванић наводећи примере романескних и драмских дела, која садрже ознаку „слика” у свом наслову или поднаслову (в. Иванић 1990: 304-305). 
закових романа ${ }^{10}$. Премда овај француски термин упућује превасходно на поступак сценичности, могуће је маркирати истоветну тежњу и намеру, сродну идејну усмереност ових писаца ка миметизму и нововременој естетизацији. С друге стране, присуство „слике” у (под)насловима српских драмских дела (Јован Суботић, Сан на јави: слика из ирошлосиич сроске, Шапчанин, Милош у Лайинима, слика у јеgном иину; Коста Трифковић, Млаgости Досииееја Обраgовића, слика из животиа у итри иина; Јанко Веселиновић и

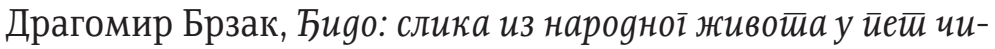
нова са иевањем и иірањем $)^{11}$ иде у прилог тези о сличности "слике” и „сцене”. Мишљења смо да ова појава - употреба „слике” у епици, лирици и драми - поред захтева за „фотографисањем” и „сликањем” стварности, открива и преображаје деветнаестовековне друштвене и књижевне свести засноване на идеји о историчности наших чула (в. Џејмсон 1984: 281).

Фредрик Џејмсон у својој марксистичкој критици представио је дијалектичку повезаност позитивистичке теорије опажања и естетичког покрета - импресионизма - за који се обично мисли да је супротан позитивистичкој идеологији. Премда је импресионизам по духу заиста антипозитивистички, могућно је ипак успоставити извесну паралелу с обзиром на сличне реакције поводом конкретне историјске ситуације, заједничке одговоре: „на рационализацију и опредмећивање у капитализму касног XIX

${ }^{10}$ Реч је о следећим Балзаковим романима: Scènes de la vie privée, Scènes de la vie de province, Scènes de la vie parisienne, Scènes de la vie de campagne, Scènes de la vie politique, Scènes de la vie militaire и др.

11 Термин „слика” до данас се задржао у (под)насловима драмских дела. Као потврду актуелности овог термина наводимо примере: Владимир В. Предић, Јесењи ловаи: слике са лейовања; Деана Лесковар, Слике жалосних gоживљаја: йрилойија и др. 
века" (Џејмсон 1984: 276). У свим реалистичким жанровима постоји завидан слој „опажајне” лексике, сходно реализацији поетике реализма као поетике „ока” и „уха”, али нам се чини да су чиниоци чулног апарата, „опажајући” подаци и учесталост глагола 'видети' ('погледати') знатно заступљенији у краћем прозном жанру - слици. Чак и ако би таква лексика у подједнакој мери обележавала све жанрове реализма, у слици препознајемо један одлучан захтев за „виђењем”, нужност „сагледавања” и „посматрања” света, наглашеност неопходности да се неко од јунака или имлицитни читалац/гледалац усмери ка визуелизованим фикционалним представама. Одломци из слике „Матере” Милорада Поповића Шапчанина илуструју нам тај приповедни налог, ту примораност да се речима објекти „виде”:

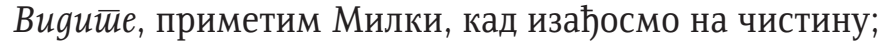

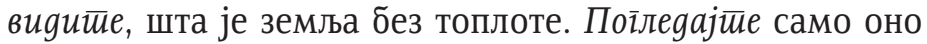
сухо грање, што се скоцало на високим деблима, па онда ове поточиће, што се изгубише под притиском силнога снега, који је попадао по оној леденој кори, што се ухватила на њиховим уским површинама, йоіллеgајйе; велим то, па ми кажите, не изгледа ли сад земља са овим снегом као мртвац, застрвен бледим самртничким покровом? (Шапчанин 1865: 124)

Тако отприлике мисле матере; а да ли су и наше матере тако паметовале, изволише, ga виguмо. (Шапчанин 1865: 97-98) [курзив А. Ж.]

Истоветни позив за „виђењем” препознајемо као поступак који није увек обликован наведеним глаголима, постоје одломци чија структура пројављује исту функционалност услед имлицитног и подразумеваног „посматрања" прикљученог радњи представљеног света, као што је случај у наредном примеру из Игњатовићеве слике „Једна женидба": 
Опет окрену други разговор, кад наједанпут фрајла

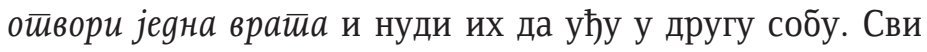
уђу. Кад је Љуба вияео шта има ту, језа га чисто напада од йоілеga на многе лепе ствари. Ту је диван од кадиве црвене, па какво огледало, па дугачке фиранге, па сат што свира! (Игњатовић 1951: 86) [курзив А. Ж.]

Премда описи у сликама подробно перспективизују детаље, чини нам се да ти описи нису само индикација кванитета и довољности података о реалном свету већ и својеврсна утопијска компензација за материјалистичку и економску стварност. Како је дошло до поделе рада у људској психи, до распарчавања спољашњег света на различите самосталне делатности, тако се појавила потреба за очувањем перцепције, за одржањем апстрактних форми постојања, за ослобађањем енергије опажања, што је условило настанак нових жанрова, пејзажа превасходно, у коме посматрање природе без људи није бесмислена већ оправдана делатност (в. Џејмсон 1984: 280-290). Мишљења смо да се у том смислу може посматрати и настанак слике као жанра и употреба термина „слика” у лирици и драми. Модели који, према Џејмсону, обликују тачке гледишта приповедача или посматрача јесу „метафора и идеал позоришног представљања" (Џејмсон 1984: 284). Имлицитни читалац као да мора да „заузме став позоришног гледаоца у односу на садржину приповедног" (Џејмсон 1984: 284), и додаћемо, драмског или лирског дела. Отуд, истоврсну стилистичку производњу, прерађивање и прекодирање података у термине „опажања”, декларацију за независношћу слике као такве, разумевамо у смислу дејства стратегије естетизације, којој су се свесно, или боље рећи несвесно, прикључили и писци српског реализма. У наведеним околностима термин „слика” приближио се значењима „сцене” и „призора”, те се учинио 
погодном и адекватном (под)насловном смерницом како драмских тако и лирских ${ }^{12}$ и приповедних дела.

Требало би имати у виду и сцену као кодни систем културног понашања човека 19. века, о чему нам казује Лотман у својим семиотичким радовима. Свакодневни живот уобличавао се према идеалима драмске литературе, посебно током прве половине 19. века, те се извесни рецидиви управљања живота према драмској сценичности могу регистровати приликом употребе термина „слика” и у реализму. "'Театрализација' и ритуализација одређених видова екстратеатралне стварности, ситуација у којој је позориште постало модел актуелног понашања" (Lotman 1975: 155 $)^{13}$, чини нам се, задобиле су нову модификацију током епохе реализма, остале сакривене и преслојене реалистичким језиком, сачуване захваљујући термину „слика”. Као слика у сликарству, и „слика” у књижевној уметности подразумева знаковну стварност, јер „целокупни свет, када постане драматизован, реорганизује себе према законима драмског простора, у коме појаве постају знаци тих појава" (Lotman 1975: 155). На основу овог мишљења можемо се запитати да ли је друштвени свет друге половине 19. века већ био „драматизован”, те се тај манир пренео и на књижевне врсте, или је пак литература тежила очувању драмског и поетског језгра пружајући

12 Термин „слика” налазимо у поднасловима лирских песама и песничких циклуса В. М. Јовановића и Љубомира Петровића. Термин прати и наслове књижевноисторијских студија од Ђорђа Рајковића до Јована Скерлића, чија је студија о Милици Стојадиновић Српкињи једна „књижевна слика” (в. Иванић 1990: 305). Додаћемо овом низу и Андрићев есеј о Вуку Караџићу под насловом „Три слике из живота Вука Караџића".

13 Напомена: сви наводи из Лотмановог чланка „Theater and Theatricality in the Order of Early Nineteenth Century Culture” дати су у нашем преводу. 
отпор научној и материјалној стварности. Како год да се одвијао тај процес, као утицање драмске литературе прошлости на живот, или као дејство живота на реалистичку књижевну продукцију, термин „слика” архивира својства литераризације, те се захваљујући томе удаљава од документарности.

Стилска пракса реалистичке слике постала је књижевни еквивалент импресионистичке стратегије у сликарству, о чему нам могу посведочити закључци из историје уметности ${ }^{14}$ : „Док су раније сликари ишли испред писаца, сада писци повлаче за собом сликаре. И они врше анализу светлости и тонова, разлучују тон, да би га појачали, на састојке који ће се у оку опет здружити, бележе своје визуелне сензације." (Ибровац 1940: 21) Трудећи се да одговоре захтевима поетике, приповедачи наглашавају порекло слике („слике из сеоског живота”, „слике изучитељског живота”, „слике из ђачког живота”), оправдавају очекивања читалачке публике и књижевне критике, те се (под)наслов може дешифровати као укрштај литературе и живота, поетизације и депоетизације, будући да је и позитивистичка свест доба увиђала како „брзо пребрзо нестају слике, с којима се природа око нас титра! Огледало их није кадро задржати, а и у оку нашем за тили час се разликују." (Андрејевић 1978: 142) Немогућност подударања стварносног и фикционалног происходи управо из научног поимања света, о чему је још 1858. године казивао Јован Андрејевић Јолес у свом научном есеју о фотографији, будући да „видело спада у колорит живота са безбројним чудним променама његовим" (Андрејевић

14 „У трећој епоси, после 1870, научни и реалистички дух у књижевности, дух анализе, одговара у сликарству йленеризмy (plein-air) и имиресионизму, случајно названом тако по једној Монеовој слици изложеној 1874. у Салону Одбачених." (Ибровац 1940: 21) 
1978: 154). Природни и друштвени свет разумевају се као сфере које су непрестано у кретању, фотографија их само може овековечити и зауставити на тренутак. Ликовно или књижевно дело, чак и онда када то покушава, не постиже, слике из живота „једина фантазија на дуже пригрлити и у тајном ковчежићу своме сачувати уме, да их после многих година оданде на видик изнесе и у својим бојама урешене на платно упише, или да у њих дивном речи нов живот суне" (Андрејевић 1978: 142). Уколико узмемо у обзир сва значења речи 'слика' - производ сликарства, фотографија, призор или лик, књижевни опис, сећање, представа, имагинација, особа или прилика, стилски поступак, књижевна скица или део драмског чина (Речник срйскохрвайскоїа книжевної језика 1990: 854-855) - можемо наслутити како се одвијала еволуција слике од „фотографије” до „визије”, пролазећи кроз два начина подражавања, настајући према појмовима „којима се означавају трансмисионе релације засноване на процесу изједначавања текстуалног и стварносног (копирање, имитирање, пресликавање)" (Чорбић Вукићевић 1998: 22) и настављајући своје развиће према појмовима „трансмутационих релација заснованих на процесу разједначавања (улепшавање, идеализовање, бирање типичног)" (Чорбић Вукићевић 1998: 22). Потврду усмерености слике ка симболистичкој пројекцији проналазимо посебно у наративима Илије Вукићевића, као што илуструје следећи пример из слике „Рождество твоје”:

- Село! - рече мој кочијаш и лако мрдну главом на ту страну. Та чудна и непокретна слика имађаше нечега тајанственога у себи. Учини ми се као да се над њим разапињу снажна, џиновска крила, која га од свега осталог одвајају, под којима се црне тамне и неосветљене сеоске кућице. Оне, у тој даљини, губе сваку јасну контуру, па им се крајеви везују један за други, расипају се у мраку, и личе на мале кабасте пластове. (Вукићевић 19??: 94) 
Вукићевићев злослутни опис села, у којем живи жалосни и запуштени чиновник осрамоћен синовљевим преступима, прекорачује границе реализма и производи драстично неочекивану визију света, будући да њени делови „губе сваку јасну контуру”, те стичемо утисак да се свет тек ствара, тек раскриљује делимице, или створен урања у маглушасту дубину, отима се погледу и као да нестаје, не дозвољава потпуну идентификацију и „фотографисање” допуштајући људској свести да памти само његове обрисе и сенке. Описивање неразазнатљивог света посведочава нам да су писци српског реализма прихватали упутства књижевних критичара, који су „наглашавали како 'слика' не смије бити проста копија оригинала и како претпоставља имагинативну радњу умјетника" (Иванић 1988: 269), шта више јунак Вукићевићеве слике као да долази у „међупростор, у догађај другости језика и његовог света, 'ослобођен' од стварности, реалистичке репрезентације, од традиције писања" (Бошковић 2012: 50).

Друштвени контекст утиче на стварање књижевних форми и манипулише условима актуализације тих форми у конкретним литерарним делима. Дело се разумева као укрштај различитих социолеката, разнородних друштвених говорних жанрова, стога не опстаје као аутономна формално-структурна целина. Слика као форма реалистичке прозе очитује различитост стилова и вишејезичност, важне претпоставке идеолошке критике. С друге стране, савремена историјска поетика не опозива појам жанра, већ назначава његову еволутивну променљивост, неједнообразност, нормативну отвореност.

Стога је и метафора о 'родном', 'генеричком' својству књижевне творевине тек условна; - о припадности књижевног дјела неком 'роду' или 'врсти' не може се говорити као о објективно диктираној припадности, већ само као о 'сродству по избору', тј. као о сличности на основу 
најопштијих обиљежја структурисања текста које аутор прихвата и на свој начин у дјелу реализује. (Брајовић 1995: 18-19) [курзив Т. Б.]

У том смислу, покушаћемо да скицирамо композиционе карактеристике слике као књижевног жанра, имајући на уму све варијантне могућности и одступања, што неће бити предмет овог истраживања. Издвојићемо само кључне поступке, који могу помоћи приликом разликовања слике и приповетке, наводећи примере који су жанровски „чистији”. Борис Успенски у студији „Поетика комиоозиије; Семиойика иконе" наглашава важност опсервације почетка и краја уметничког дела, јер посебно истакнути почетак или крај могу бити од значаја за разумевање система семиотичке корелације друштвеног и личног искуства. Осим тога, композициони поступак „оквира" додељује ликовном и књижевном делу симболичку вредност, па уколико бисмо желели да свет видимо „као знакован, потребно је (мада не увек и довољно) да поставимо било какве границе: управо границе и творе слику"

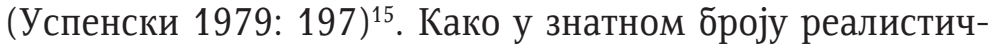
ких слика примећујемо организацију фикционалног света с тачке гледишта страног посматрача, који у први мах не припада приказиваном простору, а потом се у њему налази као учесник или сведок, поступак „оквира” означавамо пресудним за слику као композициони склоп ${ }^{16}$. На при-

${ }^{15}$ Борис Успенски скреће пажњу и на значење глагола 'насликати', које је у појединим језицима у етимолошкој вези са глаголом 'ограничити' (в. Успенски 1979: 197).

${ }^{16}$ Поступак „оквира” није специфична карактеристика искључиво слике као жанра, појављује се у свим видовима реалистичке прозе. Контекстуализацијом овог поступка у слици, уочавањем односа са другим композиционим поступцима, приближићемо се одређеним организационим комбинацијама, које ће нам омогућити сагледавање композиционих начела реалистичке слике. 
мер, у „Малим сликама из рата” Ђуре Јакшића, сликама Јанка Веселиновића „На прелу” или „Момче”, те Вукићевићевом „Мишку Убојици”, „Стики” или „Искушењу”, примећујемо прелазак са спољне на унутарњу тачку гледишта, пре свега на просторно-временском плану, будући да се приповедач након припремних радњи, размишљања или разгледања околине одлучује на путовање. Путовање је у различитим сликама друкчије устројено, од кретања на дужи пут ка удаљеном месту до краткотрајне шетње ка цркви, школи, прелу или механи. Слике обично подразумевају приповедача-путника, којег можемо определити готово као неопходну фигура, јер омогућава реконструкцију тачке гледишта субјекта, доприноси занимљивости приказивања услед упоредивости са неком реалном позицијом. „Реални” посматрач олакшава рецепцију приче „о стварним догађајима” и чини да појаве добијају одређена значења. Непосредно пре кретања на пут или приликом доласка у нови простор неретко следи опис природе. Премда су описи природе карактеристични и за приповетке, у сликама чешће имају неку од иницијалних позиција. Промена тачке гледишта уочљива је приликом ступања јунака у нови простор, што нам потврђује извесну сличност са Тургењевљевим прозама у Ловчевим зайисима. Пишући о лектири Илије Вукићевића, Љубомир Јовановић напомиње да је Вукићевић пре свега читао Тургењевљеве списе. У низу Вукићевићевих слика присутан је утицај руског писца, будући да „велики руски писац приповеда у Ловиевим зайисницима своје ловачке доживљаје и познанства па изнесе, у неколико јасних потеза, коју сељачку душу, исприча често у неколико реченица судбину, обично интиман душевни догађај, рускога мужика" (Јовановић 1987: 483-484). Додали бисмо, знатан број слика српског реализма наликује овом типу руске прозе, који је парадигматичан за разумевање слике као жанра како у руској 
тако и српској књижевности. Активирање „оквира” имамо и у следећим примерима:

Изнутра по широким ходницима чуло се тихо корачање; после тога зашкрипе врата и у исти мах чујеш испрекидане гласове муке и бола... Срце ти брже закуца, колена ти поклецују, и са стрепећим срцем уђеш у те големе просторије, где те никакав осмех, никакво весело лице неће у тужноме путовању срести! (Јакшић 1978: 40)

И он се диже са свога места, па оде право куд је наумио... Сунце је високо, па чисто пали земљу кроз густо лишће у „Коларчетовој” башти, рано је било: једва ако је превалило два сата по ручку, и нема никога, само један господин посадио се за астал у сенци, пред њиме је сатљик мађарата, па онде седи, пије и нешто дубоко премишља... (Јакшић 1978: 284)

Слике могу садржати и низ мањих микроцелина, јер свака од тих целина може бити организована према истоветним композиционим принципима, тј. смењивањем тачака гледишта, као што је случај у Игњатовићевој слици „Једна женидба”, где свака ситуација, осим последње у којој се остварује женидба, бива трострука: упознавање са девојком, ценкање око мираза и нагли одлазак. Епизоде се смењују, нарација је маркирана „прекидима” и „скоковима”, те се „слика" све више претвара у „мозаик” наместо очекиване целовитости и кохерентности „прецртаног” света. Ипак, удруживање тих ситнијих нарација можемо вредновати попут смењивања колорита у ликовном делу, као слојевити карактер просторног система реалистичке слике. На композиционом нивоу, визуелизација дисконтинуираног света може се определити у смислу „слике у слици" (в. Успенски 1979: 215). 
Редослед поступака у сликама не утиче значајније на конструкцију приказивања света. Нашим истраживањем важно је обухватити делимичну правилност у њиховом распореду, тежњу ка успостављању јединственог жанровског обрасца. Стога, неопходно је напоменути да привилеговано место у композицији слике имају описи људских фигура, екстеријера или ентеријера, углавном након ступања јунака у нови простор. Неретко се ти опсежни дескриптивни одељци уређују поступком „каталогизације". За почетак радње или говора о догађајима, као једна врста приповедног предуслова, важан је и сусрет приповедача са споредним ликовима или ликом који ће задобити улогу причаоца. Тек након тога остварује се техника „сказа”, карактеристична за овећу скупину слика, техника која је најважније композиционо и жанровско обележје слике. Није неизоставна особина овог жанра, али нас усмерава ка ономе што је у слици главно - ка причању. Како су чиниоци радње у сликама редуковани, свет се устројава законима причања. У Вукићевићевим сликама поступци „сказа” формирани су говором књижевних ликова, а првостепени приповедач постаје у појединим примерима једини слушалац, као у сликама „Стика”, „Искушење”, „Горак хлео̄” и др. Међутим, у појединим сликама недостаје уведени причалац, „сказ" се формира речима првостепеног наратора, који покушава да изгради илузију усменог приповедања апострофирајући читаоце. „Сказ” је саставни део приповедака и романа, те се ова техника не може приписати искључиво једном жанру, међутим, положај који „сказ” заузима у сликама и усредсређеност на један значајнији или више незнатних догађаја, почесто и на једну личност, могу бити индикативни за диференцијацију слике. Да ће и дијалог у форми питања и одговора имати важну улогу у композиционом склопу слике, антиципирано 
је у Живоиоооиисанију (1833) Јоакима Вујића и Дневнику (1861) Косте Трифковића. Скренувши пажњу на одломке који тематизују сусрете с граничарима-хајдуцима, Васо Милинчевић их одређује као цртице, будући да представљају сведочанства „о једном времену и једној друштвеној појави" (Милинчевић 1978: 238). Премда су ти одломци-цртице краћи од реалистичких слика, они у композиционом смислу представљају окосницу будуће слике. Цртица као жанр наликује слици и устројава се истим принципима, разлика се састоји једино у томе што је сваки поступак у њој минимализован. Међутим, и у поменутим цртицама из Вујићеве и Трифковићеве мемоарске прозе наглашене су улоге причаоца и причања, будући да је Трифковић „забележио у свом Дневнику нека Боројевићева причања о 'карактеристики' граничарској" (Милинчевић 1978: 237). Такође, знатан део Вујићеве цртице обухвата дијалог са једним харамбашом. У сликама, слично као и у цртицама, овај поступак се углавном појављује само једанпут. Употребом „оквира” наговестили смо и завршетак слике - обрнутим поступком у односу на почетак - прелазак приповедача с унутарње на спољну тачку гледишта приликом напуштања приказиваног простора. Чини се, таква промена система доживљавања била је приповедачима неопходна како би из нове перспективе, након „сликања” света, самерили ефекте „насликаног”. Такав завршетак слике сличан је крају бајке, где приповедач финалним формулама означава прелазак од живота бајке на свакодневни живот (в. Успенски 1979: 203). У наредним сликама можемо приметити како такав завршетак функционише:

$\mathrm{Ej}$, кочијашу, живље крени и здраво да сте ви који ме чекате. (Вукићевић 19??: 109) 
Стигох кући. Жена ми даде писмо једно. Отворих. Мој познаник, кмет из Ж... јавља ми, да је крава у његову селу, него да пожурим што пре могу. (Веселиновић 1896: 44)

Изиђосмо из куће. Иђасмо лагано, сваки својим мислима обузет. Сетих се причања Видина... (Веселиновић 1896: 26)

Овакви завршеци могу нам се учинити слабим и недејственим, ипак, захваљујући њима могуће је поседовати сугестију о недовршености теме. Почетак и крај истовремено сигнализирају да је говор о теми окончан, али управо та тежња ка свеобухватности ствара идеју о незавршивости дијалога, „сказа”, јунака (в. Успенски 1979: 210). Премда слика у основи тежи значењско-естетској парцијалности и фрагментарности (в. Иванић 1976: 104), она нам се услед почетка и завршетка чини целовитом и заокруженом формом приповедања, међутим, никад није представљена целина, јер „један наративни свет, као хендикепиран, не представља максимално и потпуно стање ствари" (Еко 2001: 202).

На основу свега изреченог, можемо слику определити као жанр у којем речи превазилазе ситуације, временска и просторна линеарност бивају неретко прекинути временом и простором приче, фабула бива неразуђена и сведена. Тематика се развијала и усложњавала постепено: од женидбе, породичних односа, сеоских прослава (Игњатовић, Шапчанин, Адамов, Веселиновић) преко друштвено проблематичних питања из учитељског живота (Веселиновић) или ратне стварности (Јакшић) до метафизичких слутњи добра и зла (Вукићевић, Ранковић, Драгутин Илић, Матавуљ). Када су посреди процеси канонизације и деканонизације жанрова у српској књижевности, ваља напоменути да средином 19. века проза Јована Суботића по- 
казује склоност ка прихватању нових жанровских термина из шире националне традиције, будући да се у наслову његових дела поред одреднице 'новела' појављује и руски термин 'образ'17. Такав поступак упућује нас заправо на прву фазу распада класицистичког система и најављује могућности за канонизацију новонасталих врста, које у другој фази добијају називе из уже националне традиције, као што је то случај са „приповетком” и „сликом” (в. Иванић 1990: 302). Ипак, ваљало би имати на уму и извесно чување старих приповедних схема под новим именима, за шта налазимо пример баш у Суботићевој прози, јер његови „образи” не представљају прве примере жанра слике у нашој књижевности, већ насловом најављују конципирање и прихватање нововремених облика.

Будући да је сликом требало реализовати најзначајније захтеве реалистичке поетике: мимезис, објективност, научно знање, вредност искуства (нарочито опажања), целовиту истину о друштву и свету, слика се Стевану Сремцу и Радоју Домановићу учинила погодном за пародирање, с обзиром на њихову тежњу ка прекорачењу граница реалистичког дискурса, поигравању ондашњим литерарним конвенцијама, демистификацији и раскринкавању реалистичке илузије веродостојности. Крајем епохе реализма ови писци наслутили су нове књижевне идеје, које ће преовладати у књижевној теорији и пракси током 20. века: постоји само једна семантика фикционалности. „Фикционални светови нису подређени тежњи ка вероватности, истинитости и веродостојности; на њих утичу историјски променљиви естетички фактори: уметничка стремљења, типолошке или генеричке норме, епохе и ин-

17 Посреди је Суботићево дело Женски јунак: новела: образ из последњег покрета, штампано у наставцима 1851. и 1852. године у часопису Сербски лейойис. 
дивидуални стилови." (Долежел 2008: 31) Одређујући у (под)насловима своје наративе као слике: „Чича Јордан: једна слика", ,'Чесна старина!...': слика из друштва”, „Аца Грозница: слика из Бачке", Сремац је копирајући клишетирани начин насловљавања реалистичких слика изравно започео своје пародирање и вероломство читалачког хоризонта очекивања. Сва три остварења усмерена су на преиспитивање „научног знања”, методе опажања и слушања у оквиру емпиријског изучавања материјалних феномена, те дестабилизацију егзактног и прецизног описа одабране појаве. Слика као реалистички жанр разумевана је попут метафоре или метонимије којом се репрезентује целовитост света, стога ће Сремац иронично изједначити слику са поуком разграђујући посредно коначне и дефинитивне истине представљане читаоцима током реализма дидактичним поукама. Наместо научне истине о човековој природи, друштвеној структури и односима, налазимо тематизацију безначајне крађе, којом Сремац девалвира идејно-естетску суштину слике и стваралачки метод реализма, јер јунаци „приповедају ситније доживљаје, опажања и искуства своја лоповска" (Сремац 1960: 319). Привидним опонашањем поступака својствених слици Сремац се дистанцирао од миметичког схватања уметности. Не само да је довео у питање статус јунака, темељни елемент структуре текста, већ је и устаљену композицију реалистичких дела, засновану на узрочно-последичној вези, учинио флексибилном, прилагодљивом нахођењу читалаца, те тако наместо учестале поуке приповедача на крају слике, примећујемо пародични завршетак, који својом усмереношћу на произвољност читалачког искуства умногоме подсећа на постмодернистичке стратегије приповедања.

Премда језик пародије у појединим остварењима жанра слике формира немогући свет и расклапа структуру реалистичке представе, он нам изоштрава вид за једно ново 
достигнуће у књижевности: успешну провокацију имагинације. Бивајући оно што слика није, пародије су у еволуцији слике као реалистичког жанра потпомогле распознавање онога што слика јесте, те допринеле прихватању слике као могућег жанра према критеријумима историјске поетике. Слику ће крајем епохе заменити краћи облици преобликовани лиризацијом, што је уочљиво у Јесењим сликама Светолика Ранковића (в. Иванић 1990: 306) и задобиће нова својства у прози Петра Кочића и Боре Станковића. Упркос томе, „слика” као међужанровски термин остаће у српској литератури сведочећи о немогућности ослобађања од једног вида мимезиса и потребе за апстрактношћу свакодневног живота посредством аутономне перцепције и њене унутрашње логике. Слика добија и своје место у систему жанрова српске књижевности и успоставља узајамни однос са појединим публицистичким облицима. Увидом у модалитете структурисања језика у жанру као што је слика, у начине израстања форми смисла које се пројављују у оквирима слике, распознајемо и интегрално значење језика, његову стваралачку ангажованост колико у постизању естетског квалитета као таквог, толико и у опстајању свести хуманитета о себи. Наше разматрање фикционалног карактера литературе и естетске достатности жанра слике унеколико може корелирати са идејом о нужности одржања имагинације, што жанр слике јамчи и у свом основном књижевном, естетском квалитету, али и у својеврсној метакњижевној равни - када слика није тек књижевно дело, дакле један облик света, него јесте и аутохтони књижевни жанр, који демонстрира нарочиту, самосвесну, самоодређујућу форму сликања света. 
ИЗВОРИ

Вукићевић 19??: И. Вукићевић, Целокуйна gела, књ. 2, Београд: Народна просвета.

Игњатовић 1862: Ј. Игњатовић, Једна женидба. Слика из живота од Јакова Игњатовића, Нови Сад: Дании, , III/ 1-11.

Игњатовић 1951: Ј. Игњатовић, Ogабране ирийовеике, Београд: Ново поколење.

Јакшић 1978: Ђ. Јакшић, Сабрана gела Ђуре Јакшића; Прийовейке и gруїа йроза, књ. 4, Београд: Слово љубове.

Поповић Шапчанин 1865: М. Поповић Шапчанин, Матере. Слика из обичнога живота, Нови Сад: Дании, VI/ 5-8.

\section{ЛИТЕРАТУРА}

Андрејевић 1978: Ј. Андрејевић, Фотографија, у: Васо Милинчевић, Из сйарих ризнииа, Београд: Рад, 142-154.

Бошковић 2012: Д. Бошковић, Модернитет и генеза епифанија у прози Лазе Лазаревића, Београд: Кюижевна истиоpuja, 44/146, Београд, 41-59.

Брајовић 1995: Т. Брајовић, Поетиика жанра, Београд: Народна књига-Алфа.

Деретић 1981: Ј. Деретић, Срйски роман 1800-1950, Београд: Нолит.

Еко 2001: U. Eko, Granice tumačenja, Beograd, Novi Sad: Paideia, Budućnost.

Живаљевић 1890: Д. Живаљевић, Из Црне Горе и ириморја. Приповијетке Симе Матавуља (...) Цетиње, 1889, Загреб: Коло, I/26, Загреб, 439.

Живковић 1982: Д. Живковић, Евройски оквири срйске књи-

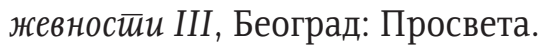

Живковић 1994: Д. Живковић, Термин „слика” код српских приповедача у XIX веку, у: Д. Живковић, Евройски оквири срйске књижевности и, књ. 2, Београд: Просвета, 206213. 
Ибровац 1940: М. Ибровац, Сликарстиво и књиневносй у Франиуској, Београд: Штампарија Милана Сибинкића.

Иванић 1976: Д. Иванић, Срйска йрит̄овијетика између романшике и реализма: 1865-1875, Београд: Институт за књижевност и уметност.

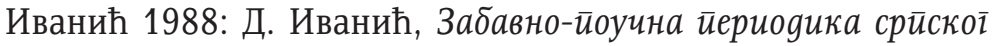
реализма, Нови Сад: Матица српска.

Иванић 1990: Д. Иванић, Модели књижевноїа їовора: из исйоpије и йоеиике срйске књижевностии, Београд: Нолит.

Јовановић 1972: Љ. Јовановић, Илија Вукићевић, у: Миодраг Протић (прир.), Ейоха реализма, Београд: Нолит, 156184.

Јовановић 1987: М. Јовановић, Слике из сеоскоі живота. Пише Јанко Веселиновић, учитељ, у: Предраг Протић

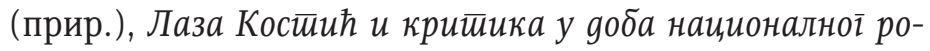

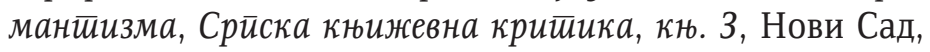
Београд: Матица српска, Институт за књижевност и уметност, 244-254.

Лотман 1975: Iu M. Lotman, Theater and Theatricality in the Order of Early Nineteenth Century Culture, London: Soviet Studies in Literature, Vol. 11, Issue 2-3, London, 155-185.

Речник српскохрватскога књижевног језика 1990: Речник срйскохрвайскоїа књиневної језика, књ. 5, П-С, (ур.) др Михаило Стевановић, др Светозар Марковић, Светозар Матић, Павле Рогић, др Митар Пешикан, Србислава Ковачевић, др Даринка Гортан - Премк, Нови Сад: Матица српска.

Савић 1880: М. Савић, Приповетке Милорада П. Шапчанина. Књ. 1-4, Нови Сад: Лейойис Майице срйске, 49/122, Нови Сад, 122-131.

Савић 1881: М. Савић, Приповетке Милована Ђ. Глишића. Књига прва (...) 1879, Нови Сад: Срйске илусйроване новине, I/2, Нови Сад, 30-31.

Скерлић 1904: J. Скерлић, Светолик Ранковић, у: Светолик Ранковић, Слике из животи $а$, Београд: Српска књижевна задруга, V-XXVIII. 
Чорбић Вукићевић 1998: D. Čorbić Vukićević, Poetika čitanja - kritikaproze 1868-1901, Beograd: Zadužbina Andrejević. Џејмсон 1984: F. Džejmson, Političko nesvesno: pripovedanje kao društveno-simbolični čin, Beograd: Rad.

\title{
Ana S. Živković
}

\section{THE SKETCH - A LITERARY FORM \\ IN SERBIAN REALISM}

\begin{abstract}
Summary
This study examines the "sketch" as a genre and in between genre prose category in Serbian realism. The strategy of world aesthetization operates by constructing a spectator's point of view and is formed thanks to the metaphor of theatre, which may explain the presence of the term "sketch" in the works of all three literary genres.Taking the Marxist idea of historicity of human senses into account, we recognize the samples of emergence of a new genre, a new semi-autonomous literary activity - the sketch. The aim of this paper is focused on the process of genre canonization, from the periphery of the genre system to its centre, as well as the reverse phenomenon - the sketch decanonization - in which the parody has the key role. Applying ideological and structuralist method, we highlight the key compositional procedures in the sketch: journey as motivation, the protagonist's arrival to new surroundings, description of nature, description of exteriors and interiors, an encounter with a man, the question-answer dialogue, the skaz technique, the protagonist's departure. The sketch is defined as a small genre, as axiological and ideological model, which evolved into modern Serbian prose, making the nature of Serbian literary history visible.

Key words: "sketch", genre, realism, the theatre metaphor, aestheticism, historicity of senses
\end{abstract}

